\title{
HUBUNGAN KELIMPAHAN RELATIF KARANG HIDUP DENGAN KEPADATAN MEGABENTOS DI PERAIRAN WAWORAHA SULAWESI TENGGARA
}

\author{
Relation of Relative Abundance of Life Coral with Megabenthos Density \\ in Waworaha Waters Southeast Sulawesi
}

\author{
Asri Triyani Wulandari¹, Baru Sadarun², Ratna Diyah Palupi ${ }^{3}$ \\ ${ }^{1}$ Mahasiswa Ilmu Kelautan \\ Fakultas Perikanan dan Ilmu Kelautan Universitas Halu Oleo \\ Jl. HEA Mokodompit Kampus Bumi Tridharma Anduonohu Kendari 93232 \\ ${ }^{2}$ Surel: sadarunbaru@gmail.com \\ ${ }^{3}$ Surel: pratna97@yahoo.com
}

\begin{abstract}
Abstrak
Terumbu karang merupakan ekosistem yang subur dan kaya akan makanan. Megabentos merupakan salah satu komunitas hewan bentik yang berasosiasi dengan terumbu karang. Tujuan penelitian ini yaitu untuk mengetahui kepadatan megabentos (bulu babi, bintang laut, teripang, lola, kima, lobster, siput drupella, dan bintang laut berduri), mengetahui kelimpahan relatif karang hidup serta hubungan kelimpahan relatif karang hidup dengan kepadatan megabentos di Perairan Waworaha Provinsi Sulawesi Tenggara. Pengambilan data kondisi karang dan fauna megabentos dilakukan dengan menggunakan metode Belt Transect yang ditarik sejajar garis pantai dengan luasan $350 \mathrm{~m}^{2}$. Hasil penelitian yang didapatkan pada tiap stasiun adalah persentase kelimpahan relatif karang hidup di perairan waworaha termasuk tinggi dengan rata-rata persentase kelimpahan relatif karang hidup sebesar 70,28\%. Nilai rata-rata kepadatan megabentos adalah $0,070 \mathrm{ind} / \mathrm{m}^{2}$ dengan kepadatan tertinggi terdapat pada stasiun 3 yaitu $0,096 \mathrm{ind} / \mathrm{m}^{2}$, dan kepadatan megabentos terendah terdapat pada stasiun 1 yaitu $0,030 \mathrm{ind} / \mathrm{m}^{2}$. Perhitungan nilai hubungan kelimpahan relatif karang hidup dengan kepadatan megabentos didapatkan nilai $\mathbf{r}$ sebesar 0.929 bernilai positif yang artinya kelimpahan relatif karang hidup dan kepadatan megabentos memiliki hubungan yang sangat kuat.
\end{abstract}

Kata kunci: Karang, Kepadatan, Megabentos, Waworaha

\begin{abstract}
Coral reefs are a fertile and rich in food. Megabenthos is one of the benthic communities associated with coral reefs. The purpose of this study was to determine the density megabenthos (sea urchins, sea stars, sea cucumbers, lola, clams, lobsters, drupella snails and thorny starfish), to idenfity the relative abundance of life coral, and relative abundance of life corals with mengabenthos density in Waworaha Waters, Southeast Sulawesi. Data collection of megabenthos coral and fauna conditions was carried out using the belt transect method which was drawn, to the coastline with an area of $350 \mathrm{~m}^{2}$. The results of the study found that the percentage of the relative abundance of life coral at each station was relatively high with an average relative abundance percentage of life coral at 70,28 . The mean density of megabenthos was $0,070 \mathrm{ind} / \mathrm{m}^{2}$ with the highest density found at station 3 , which was $0,096 \mathrm{ind} / \mathrm{m}^{2}$, an the lowest megabenthos density was at station 1 , which was $0,030 \mathrm{ind} / \mathrm{m}^{2}$. The relative abundance of live coral with megabenthos density ( $\mathrm{r}$ value) was 0,0929 and had positive value which means that the relative abundance of live coral and megabenthos density had a very strong relationship.
\end{abstract}

Keywords: Corals, Density, Megabentos, Waworaha

\section{Pendahuluan}

Terumbu karang memiliki beberapa peranan seperti peranan secara ekologi dan secara fisik. Secara ekologis terumbu karang merupakan tempat organisme hewan maupun tumbuhan mencari makan, berkembang biak serta berlindung. Secara fisik berfungsi sebagai pemecah gelombang alami yang melindungi pantai dari erosi (Suryanti, Supriharyono dan Indrawan W., 2011).
Daerah terumbu karang umumnya banyak dijumpai hewan mollusca seperti gastropoda dan bivalvia. Hewan mollusca banyak menempati daerah terumbu karang, berasosiasi dengan karang karang dengan menjadikan terumbu karang sebagai tempat hidup.

Megabentos merupakan organisme yang berukuran lebih dari $1 \mathrm{~cm}$ yang hidup menetap 
(sessile) dan memiliki daya adaptasi yang bervariasi terhadap kondisi lingkungan. Megabentos memiliki peranan penting dalam jaring-jaring makanan. Megabentos terbagi atas empat kelompok seperti karang, echinodermata, moluska, dan crustacea, kehadiran kelompok jenis ini sangat dipengaruhi oleh kualitas ekosistem terumbu karang yang artinya semakin baik kondisi terumbu karang maka semakin besar pula peluang tingginya keanekaragaman megabentos, begitu juga sebaliknya (Terangi, 2007). Fauna megabentos yang dijadikan sebagai indikator pemantauan kondisi karang ada delapan jenis. Dari delapan jenis biota tersebut kemudian dibagi menjadi tiga kelompok besar berdasarkan nilai atau manfaatnya bagi masyarakat dan ekosistem terumbu karang.

Terumbu karang merupakan tempat bagi sebagian oganisme-organisme yang berasosiasi didalamnya termasuk megabentos (Romimoharto dan Juwana, 2001). Tingkat kesehatan karang juga ditentukan oleh berlimpah atau berkurangnya biota megabentos yang hidup berasosiasi di dalamnya (Sumadhiharga, 2006). Keanekaragaman jenis yang tinggi dapat dipengaruhi oleh kondisi atau kualitas ekosistem terumbu karang yang artinya semakin baik kondisi terumbu karang maka semakin besar peluang tingginya keanekaragaman megabentos, begitu juga sebaliknya (Cappenberg, 2006).

Faktor yang mendasari penggunaan bentos sebagai organisme indikator kualitas perairan adalah karena sifat bentos yang relatif diam atau memiliki mobilitas yang rendah sehingga sangat banyak mendapat pengaruh dari lingkungan (Agustinus dkk., 2007). Sedangkan peran secara ekonomis yaitu beberapa jenis megabentos misalnya lobster dan teripang memiliki nilai ekonomis yang cukup tinggi di pasaran sehingga sebagian masyarakat menjadikan dua biota megabentos ini menjadi sumber mata pencaharian.

Perairan Waworaha dijadikan sebagai sumber mata pencaharian bagi sebagian besar masyarakat yang umumnya bekerja sebagai nelayan. Ditambah lagi rata-rata masyarakat setempat menjadikan karang sebgai bahan bangunan, selain itu Perairan Waworaha juga dijadikan sebagai tujuan wisata bagi masyarakat lokal. Adanya aktifitas-aktifitas tersebut juga akan menimbulkan dampak bagi kondisi ekosistem terumbu karang yang ada di Waworaha.

Tujuan penelitian ini yaitu untuk mengetahui kelimpahan relatif karang hidup, mengetahui kepadatan megabentos, mengetahui hubungan kelimpahan relative karang hidup dengan kepadatan megabentos di Perairan Waworaha, Kecamatan Soropia, Kabupaten Konawe. Sedangkan kegunaan dari penelitian ini diharapkan dapat menjadi data awal tentang bagaimana hubungan kelimpahan relatif karang hidup berdasarkan kepadatan megabentos di Perairan Waworaha serta dapat menjadi acuan untuk penelitian-penelitian selanjutnya.

\section{Bahan dan Metode}

Penelitian ini dilaksanakan pada bulan April 2017 bertempat di Perairan Waworaha, Kecamatan Soropia, Kabupaten Konawe Provinsi Sulawesi Tenggara. Penentuan titik stasiun penelitian dapat dilihat pada Gambar 1 menggunakan metode purposive sampling. Penentuan 3 titik stasiun yang dipilih dianggap dapat mewakili kondisi terumbu karang pada Perairan Waworaha. Adapun peta lokasi penelitian dapat dilihat pada Gambar 1.

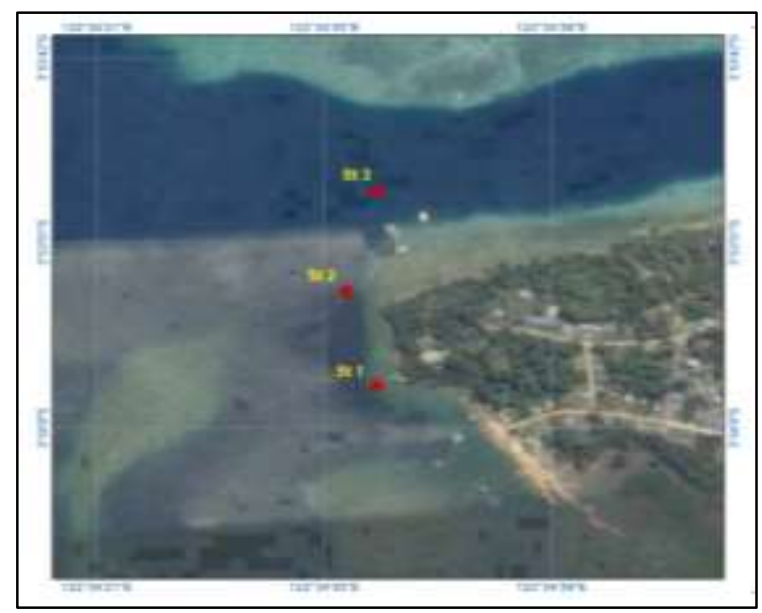

Gambar 1.Sketsa Lokasi Penelitian

Metode yang digunakan dalam pengambilan data relatif karang hidup adalah belt transect. Data yang didapat diantaranya penutupan karang, dan densitas koloni. Transek 
garis menggunakan roll meter yang dibentangkan sejajar garis pantai sepanjang 70 x $5 \mathrm{~m}\left(350 \mathrm{~m}^{2}\right)$ dengan dua kali ulangan.

Pengambilan fauna megabentos juga dilakukan dengan menggunakan metode belt transect dengan luasan $350 \mathrm{~m}^{2}$ (Munro, 2013) dengan menggunakan peralatan SCUBA. Metode ini dilakukan dengan cara sebagai berikut:

1. Menarik garis dengan pita berskala (roll meter) sejajar garis pantai dengan panjang $70 \mathrm{~m}$ pada tiap stasiun, garis pantai selalu berada di sebelah kiri penyelam sewaktu menarik pita transek dari titik $0 \mathrm{~m}$ sampai 70 $\mathrm{m}$ dengan lebar observasi $2,5 \mathrm{~m}$ ke kiri dan kanan garis transek, sehingga luas pemantauan menjadi $350 \mathrm{~m}^{2}$.

2. Setelah pita transek terpasang, Melakukan pengamatan dan pencatatan biota dan jumlah megabentos (teripang, kima, lobster, lola, bintang laut berduri, siput Drupella spp., bulu babi, dan bintang laut biru).

Pengukuran oseanografi fisika-kimia di lapangan seperti suhu, salinitas, kecerahan, kecepatan arus, $\mathrm{pH}$ dan arus, dilakukan di setiap stasiun pengambilan data kemudian disajikan menurut kedalaman setiap stasiun dan dianalisis secara deskriptif dengan bantuan tabel atau grafik.

Kecepatan arus dihitung dengan menggunakan rumus persamaan,

Kecepatan arus $=\frac{m}{s}$

Keterangan yang ditempuh sampai tali merenggang

Pengolahan data kelimpahan relatif karang hidup menggunakan Microsof Office Excel 2003. Persentase tutupan karang hidup dihitung berdasarkan persamaan berikut :

Kelimpahan

$$
=\frac{\text { jumlah koloni ke } i}{\text { total koloni seluruh lifeform }} \times 100 \%
$$

Kepadatan jenis megabentos didefinisikan sebagai jumlah individu jenis stasiun dalam satuan persegi atau kubik. Kepadatan dihitung dengan formulasi berikut (Harvey, 2008):

$D=\frac{\mathrm{n}}{\mathrm{A}}$

Keterangan:

$\mathrm{D}=$ Kepadatan megabentos (ind $\left./ \mathrm{m}^{2}\right)$ $\mathrm{n}=$ Jumlah individu megabentos di tiap stasiun (ind)

$\mathrm{A}=$ Luas daerah pengamatan $\left(\mathrm{m}^{2}\right)$

Pengolahan analisis hubungan kondisi terumbu karang hidup dengan kepadatan megabentos menggunakan rumus Sugiyono (2007) sebagai berikut:

$r=\frac{\mathrm{N} \Sigma \mathrm{XY}-(\Sigma \mathrm{X})(\Sigma \mathrm{Y})}{\sqrt{\mathrm{N} \Sigma \mathrm{X}^{2}}-(\Sigma \mathrm{X})^{2}\left(\mathrm{~N} \Sigma \mathrm{Y}^{2}-\left(\Sigma \mathrm{Y}^{2}\right)\right)}$

Keterangan :

$\mathrm{r}=$ koefisien korelasi

$\mathrm{X}=$ Variabel yang diukur

$\mathrm{N}=$ Jumlah total sampel

$\mathrm{Y}=$ Variabel yang diukur

Selanjutnya hasil dicocokkan dengan pedoman interpretasi terhadap koefisien korelasi menurut Sugiyono (2007) berikut pada Tabel 1 di bawah ini:

Tabel 1. Kriteria Koefisien Korelasi

\begin{tabular}{cl}
\hline Interval Koefisen & Tingkat Hubungan \\
\hline $0,00-0,199$ & Sangat rendah \\
$0,20-0,399$ & Rendah \\
$0,40-0,599$ & Sedang \\
$0,60-0,799$ & Kuat \\
$0.80-1,00$ & Sangat Kuat \\
\hline
\end{tabular}

\section{Hasil dan Pembahasan}

Berdasarkan penelitian yang dilakukan pada tiap stasiun didapatkan hasil persentase tertinggi untuk kategori karang hidup terdapat pada stasiun 3 yakni $73,72 \%$, sedangkan untuk kategori karang mati presentase tertinggi terdapat pada stasiun 1 yakni $33,08 \%$. Persentase terendah untuk kategori karang hidup terdapat pada stasiun 1 yakni $66,87 \%$ dan untuk kategori karang mati terdapat pada stasiun 3 yakni $26,23 \%$ seperti yang tersaji dalam Gambar 2.

Setiap stasiun penelitian didapatkan hasil rata-rata persentase kelimpahan relatif karang hidup di lokasi penelitian adalah 70,28\% dengan kelimpahan relatif karang hidup stasiun 3 lebih tinggi bila dibandingkan dengan dua stasiun lainnya. Berdasarkan hal tersebut diketahui bahwa kelimpahan relatif karang hidup di Perairan Waworaha masih dalam kategori yang cukup tinggi. Berdasarkan lifeform karang hidup yang menyusun terumbu ditemukan 11 kategori. 


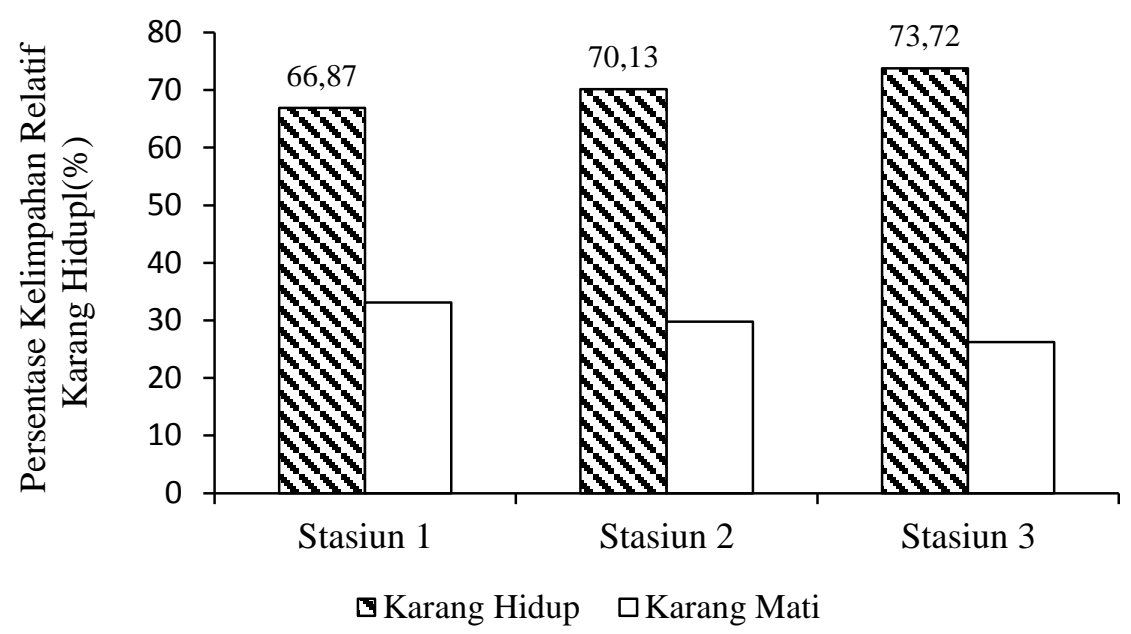

Gambar 2. Persentase Kelimpahan Relatif Karang Hidup di Setiap Stasiun

Hasil penelitian rata-rata kepadatan megabentos yang didapatkan pada Perairan Waworaha sebesar $0,070 \mathrm{ind} / \mathrm{m}^{2}$ dengan kepadatan tertinggi terdapat pada stasiun $3(0,095$ ind $\left./ \mathrm{m}^{2}\right)$, dan kepadatan megabentos terendah terdapat pada stasiun $1\left(0,029 \mathrm{ind} / \mathrm{m}^{2}\right)$.

Tingginya persentase kelimpahan relatif karang hidup pada terumbu karang di lokasi penelitian meskipun diikuti juga oleh peningkatan kepadatan A. planci diduga disebabkan karena populasi A. planci yang tidak terlalu tinggi, sehingga pemangsaan karang juga tidak terlalu tinggi. Jika populasi A. planci pada suatu ekosistem dalam status alami, maka tidak akan memberikan ancaman yang berarti terhadap ekosistem terumbu karang bahkan dapat menjaga keseimbangan ekologi di dalam ekosistem. Hal ini sesuai pendapat Bachtiar (2009), bahwa pemangsaan karang oleh A. planci yang dalam populasi rendah bersifat selektif dengan preferensi pada Pocilloporidae dan Acroporidae yang tumbuh cepat dan cenderung mendominasi ruang di terumbu. Pemangsaan selektif ini mempunyai dampak ekologi yang positif karena memberikan bantuan kepada karang yang tumbuh lambat untuk tetap tinggal di terumbu tersebut.

Kondisi lingkungan atau habitat megabentos sangat memengaruhikepadatan megabentos. Apabila kepadatan megabentos tinggi artinya habitat atau lingkungan tersebut merupakan tempat yang sesuai untuk keberlangsungan megabentos itu sendiri begitu pula sebaliknya apabila kepadatan megabentos rendah berarti habitat tersebut tidak sesuai dengan keberlangsungan hidupmegabentos tersebut.

Nilai kepadatan megabentos yang didapatkan berkisar antara 0,029-0,095 ind $/ \mathrm{m}^{2}$. Nilai kepadatan megabentos yang didapatkan di Perairan Waworaha ini lebih rendah bila dibandingkan dengan kepadatan megabentos di Daerah Perlindungan Laut (DPL) Pasi Dadawi Kelurahan Majapahit Kabupaten Buton yang mendapatkan kepadatan megabentos berkisar antara 8,27- 11,82 ind/ $/ \mathrm{m}^{2}$ (Aswad, 2014).

Tingginya kepadatan megabentos yang terdapat di stasiun 3 diduga dipengaruhi oleh persentase kelimpahan relatif karang yang termasuk dalam kategori tinggi sehingga dapat diasumsikan bahwa stasiun 3 merupakan habitat yang sesuai dengan keberlangsungan hidup dari megabentos yang berasosiasi di dalamnya. Kepadatan megabentos di stasiun 3 juga di dominasi oleh $A$. planci serta bulu babi.

Kepadatan bulu babi tertinggi terdapat pada stasiun 3, lokasi pada stasiun ini memiliki banyak batuan dan substrat keras. Stasiun ini juga memiliki persentase tutupan terumbu karang yang paling tinggi dari dua stasiun yang diamati. Banyak bulu babi yang bersembunyi pada lubanglubang yang ada pada batu tersebut. Letak stasiun ini lebih menjorok kearah laut. Diduga hal tersebut menyebabkan pada stasiun ini memiliki kepadatan yang lebih tinggi karena tempat hidup yang sesuai dan lebih jauh dari jangkauan masyarakat serta wisatawan yang berkunjung di pantai. 
Tabel 2. Kepadatan Megabentos di Setiap Stasiun Penelitian

\begin{tabular}{llrrr}
\hline \multirow{2}{*}{ No } & \multirow{2}{*}{ Biota Megabentos } & \multicolumn{3}{c}{ Kepadatan Megabentos (ind $\left./ \mathbf{m}^{\mathbf{2}}\right)$} \\
\cline { 3 - 5 } & & Stasiun 1 & Stasiun 2 & Stasiun 3 \\
\hline 1 & Teripang & 0,001 & 0,003 & 0,001 \\
2 & Lobster & 0 & 0,001 & 0 \\
3 & Lola & 0 & 0 & 0 \\
4 & Kima & 0,007 & 0,004 & 0,003 \\
5 & Bintang Laut Biru & 0,004 & 0,016 & 0,013 \\
6 & Bulu Babi & 0,010 & 0,035 & 0,041 \\
7 & Drupella spp & 0,007 & 0,006 & 0,003 \\
8 & Acanchaster planci & 0 & 0,018 & 0,034 \\
\hline \multicolumn{2}{r}{ Jumlah } & $\mathbf{0 , 0 2 9}$ & $\mathbf{0 , 0 8 2}$ & $\mathbf{0 , 0 9 5}$ \\
\hline
\end{tabular}

Sedangkan tingginya kepadatan A. Planci di stasiun 3 diduga karena biota ini menyukai jenis-jenis karang tertentu dapat dilihat pada Tabel 3 persentase karang tertinggi di stasiun 3 adalah jenis karang batu hal ini sesuai dengan pernyataan Porter (1972) dalam Nybakken (1988) mengatakan bahwa bintang laut berduri ini mempunyai pilihan makanan, yaitu spesies karang yang tumbuh cepat dan menguasai tempat. Sedangkan Piyakornchana (1981) mengemukakan bahwa A. planci lebih suka melekat pada karang batu dari jenis Acropora dan Pocillopora dibanding jenis lainnya.

Rendahnya kepadatan bulu babi pada stasiun 1 diduga dipengaruhi oleh padatnya aktivitas masyarakat seperti penambatan jangkar kapal ataupun boat, dan juga tempat lalu lalang perahu-perahu nelayan. Menurut penelitian Wulandewi (2015), tingginya aktivitas masyarakat di sekitar pantai akan memengaruhi habitat bulu babi dan secara tidak langsung akan mempengaruhi kepadatan bulu babi. Penelitian yang dilakukan oleh Yudasmara (2013) di Pulau Menjangan juga menyebutkan bahwa lokasi dimana terdapat dermaga tempat untuk bersandarnya kapal atau boat juga ikut memengaruhi persentase tutupan karang hidup sehingga mempengaruhi kehadiran bulu babi disana. Stasiun 1 merupakan daerah yang mengalami penumpukan sedimen paling tinggi bila dibandingkan dengan kedua stasiun lainnya. Keberadaan megabentos tertentu selain dipengaruhi oleh kondisi terumbu karang yang merupakan habitatnya juga dipengaruhi oleh faktor fisik kimia dari perairan itu sendiri.
Rendahnya kepadatan lobster di tiap stasiun diduga karena biota bentos ini merupakan biota yang diburu oleh masyarakat selain untuk diperjualbelikan juga untuk dikonsumsi secara langsung. Lobster memiliki nilai harga jual yang cukup tinggi di pasaran yakni mulai dari harga Rp. 30 ribu perekor sampai 1 juta perkilogramnya sehingga tidak heran biota ini menjadi buruan masyarakat. Hal ini sesuai dengan pernyataan Saputra (2009) yang menyatakan bahwa lobster merupakan komoditas perikanan unggulan yang memiliki nilai ekonomis yang tinggi dalam perdagangan produk perikanan tingkat lokal maupun internasional. Biota lola tidak ditemukan satupun di lokasi penelitian. Hal ini diduga dipengaruhi oleh perburuan masyarakat terhadap biota ini untuk kepentingan konsumsi dan kepentingan ekonomi. Di Indonesia produksi cangkang lola pada tahun 1990 diperkirakan sebesar 4000 ton/tahun, sedangkan pada tahun 1998 permintaan pasar dunia terhadap cangkang lola diperkirakan sebesar 7000 ton/tahun, dengan nilai mencapai 50-60 juta dolar Amerika (Smith dkk.,2002). Hal ini menyebabkan pemanfaatan keong lola semakin intensif. Kemungkinan keong lola telah mengalami eksploitasi yang berlebihan, sehingga jumlahnya terus menurun. Menurut Arifin (1993) Kecenderungan penurunan keong lola dapat dilihat dari penurunan hasil tangkapan (buka sasi) lola di Pulau Saparua dan Kepulauan Banda pada periode antara tahun 1979 sampai dengan tahun 1992, yaitu dari sekitar empat ton cangkang kering menjadi hanya sekitar 0.25 ton cangkang kering. 


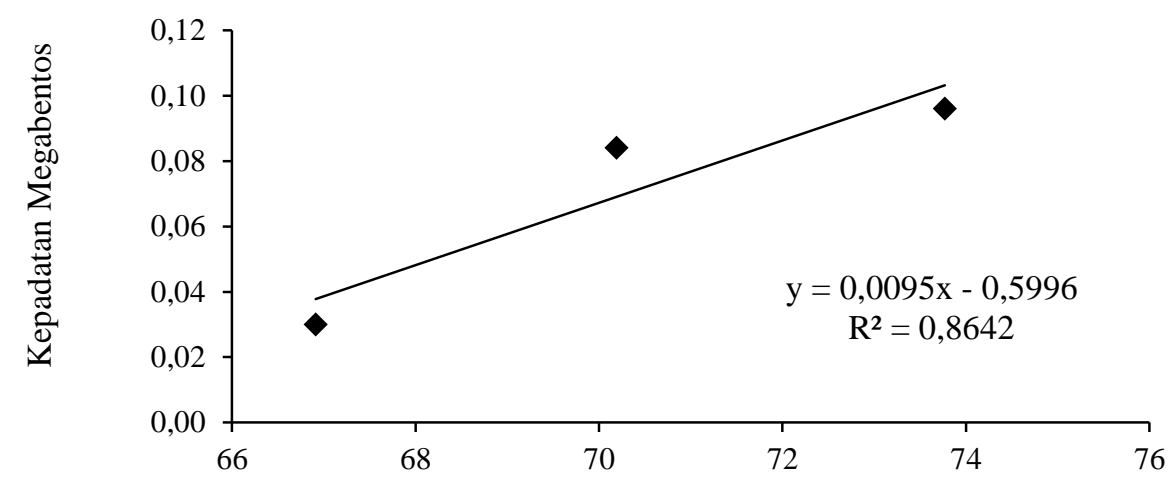

Persentase Kelimpahan Relatif Karang Hidup

Gambar 3. Grafik Hubungan Kelimpahan Relatif Karang Hidup dengan

Kepadatan Megabentos

Hasil analisis regresi kelimpahan relatif karang hidup dengan kepadatan megabentos diperoleh hubungan $y=0,009 x-0,599$, dengan nilai koefisien korelasi (r) sebesar 0,929 yang berarti hubungannya keduanya sangat kuat. Nilai koefisien determinansi $\left(R^{2}\right)=0,864$ yang berarti bahwa kelimpahan relatif karang hidup memberikan pengaruh terhadap kepadatan megabentos sebesar $86,4 \%$.

Gambar 3 menunjukan grafik linear kepadatan megabentos dengan terumbu karang yang meningkat. Hal tersebut berarti semakin tinggi kelimpahan karang maka semakin tinggi pula kepadatan megabentos yang berasosiasi dengan terumbu karang itu sendiri.. Hasil analisis nilai korelasi antara persentase tutupan karang dengan kepadatan megabentos diperoleh nilai 0,929 . Nilai korelasi yang didapatkan ini mendekati 1 yang artinya kelimpahan relatif karang hidup memiliki hubungan yang sangat kuat dengan kepadatan megabentos. Hasil analisis koefisien determinansi antara kelimpahan relatif karang hidup dengan kepadatan megabentos diperoleh nilai sebesar 0,864 yang menunjukan bahwa variabel bebas yakni presentase kelimpahan relatif karang hidup memberi pengaruh terhadap variabel terikat yakni kepadatan megabentos sebesar $86,4 \%$. Nilai ini juga menunjukan nilai korelasi positif yang artinya disetiap penambahan persentase kelimpahan relatif karang hidup diikuti dengan peningkatan kepadatan megabentos.

Berdasarkan nilai tersebut maka menunjukkan bahwa persentase kelimpahan relatif karang hidup dengan kepadatan megabentos mempunyai hubungan yang sangat kuat. Penentuan nilai korelasi sesuai dengan kriteria Sugiyono (2007). Hal ini sama dengan penelitian yang dilakukan oleh Aswad (2014) yang mendapatkan hasil analisis korelasi positif antara kondisi terumbu karang dengan kepadatan megabentos dimana nilai yang didapatkan sebesar 0,982 .

Tabel 3. Hasil Pengukuran Kondisi Kimia Fisika Oseanongrafi Perairan

\begin{tabular}{lcccc}
\hline \multicolumn{1}{c}{ Pengukuran } & Satuan & I & $\begin{array}{c}\text { Stasiun } \\
\text { II }\end{array}$ & III \\
\hline \multicolumn{1}{c}{ Parameter Fisika } & & & & \\
Suhu & ${ }^{0} \mathrm{C}$ & 29.5 & 30 & 30 \\
Kecerahan & $\mathrm{m}$ & 3.75 & 4.7 & 5.55 \\
Kecepatan Arus & $\mathrm{m} / \mathrm{s}$ & 0,11 & 0.19 & 0,27 \\
Parameter Kimia & & & & \\
Salinitas & $\mathrm{ppt}$ & 30 & 30.5 & 31.5 \\
\hline
\end{tabular}




\section{Simpulan}

Berdasarkan penelitian yang dilakukan maka dapat disimpulkan bahwa:

1. Kepadatan megabentos yang didapatkan pada Perairan Waworaha adalah sebesar $0,070 \mathrm{ind} / \mathrm{m}^{2}$.

2. Persentase kelimpahan relatif karang hidup di Perairan Waworaha termasuk dalam kategori cukup tinggi yakni sebesar $70,28 \%$.

3. Hubungan kelimpahan relatif karang hidup dengan kepadatan megabentos memiliki nilai koefisien determinansi $\left(\mathrm{R}^{2}\right)$ sebesar 0,864 dan menunjukkan nilai korelasi positif. Persentase kelimpahan relatif karang hidup berbanding lurus dengan kepadatan megabentos.

\section{Daftar Pustaka}

Agustinus, Y., A. Pratomo., D. Apdillah. 2013. Struktur Komunitas Makrozoobentos

Sebagai Indikator Kualitas Perairan di Pulau Lengkang Kecamatan Belakang Padang Kota Batam Provinsi Kepulauan Riau. [Skripsi]. Batam. Jurusan Ilmu Kelautan Fakultas Ilmu Kelautan dan Perikanan, Universitas Maritim Raja Ali Haji.

Arifin Z. 1993. Sebaran geografis, habitat, dan perikanan siput Lola (Trochus niloticus) di Maluku J Fak Perik Unsrat, 2 (1993), pp. 40-48

Aswad. 2014. Keanekaragaman dan Kepadatan Megabentos pada Terumbu Karang Daerah Perlindungan Laut (DPL) Pasi Dadawi Kelurahan Majapahit Kecamatan Batauga Kabupaten Buton. Fakultas Perikanan dan Ilmu Kelautan. Universitas Halu Oleo. Kendari

Aziz A,1997Status Penelitian Teripang Komersial di Indonesia. Oseana 22 (1):919.

Bachtiar, I. 2009. Bintang Laut Mahkota Duri (Acanthaster planci, Asteroidea). http://mycoralreef.wordpress.com/2009/01 /26/bintang-laut-mahkota-duri-

acanthaster-planci-asteroidea/. (Di akses 11 November 2017).

COREMAP- LIPI. 2014. Panduan Monitoring Kesehatan Terumbu Karang
Harvey, J.T. (2008) Abundance. Encyclopedia of Ecology (ed. by S.E.J. Fath and D. Brian),pp. 4-10. Academic Press, Oxford.

Keputusan Menteri Negara Lingkungan Hidup. 2001. Nomor : 04 Tahun 2001 Tentang Kriteria Baku Kerusakan Te rumbu Karang.

LIPI. (2008). Kondisi sebaran terumbu karang di Indonesia. LIPI. Jakarta.

Loya, Y. (1978) Plotless and transect methods. Coral reefs: research methods (ed. by D.R.Stoddart and R.E. Johannes), pp. 197217. UNESCO, Paris.

Manuputty AEW, Giyanto, Winardi, Susanti SR, \& Djuwariah. 2006. Monitoring Kesehatan Karang (Reef Health Monitoring). P2O-LIPI, Jakarta.

Martoyo J, Aji N, Winanto T. 2006. Budidaya Teripang. Penebar Swadaya, Jakarta.

Moran, P. J., 1987a. A Close Look: The Crown of Thorns Starfish. The Crown of Thorns Starfish, Australian Science Magazine, Issue 3. GBRMPA, Queensland 1987b. Starfish Outbreaks: The Great Barrier Reef. The Crown of Thorns Starfish, Australian Science Magazine, Issue 3. GBRMPA, Queensland 1990. The Acanthaster plancii (L.); Biographical Data. Coral Reefs 9; 95-96.

Muchlis. 1999. Pertumbuhan karang Acropora nobilis dan Acropora nosuta pada kawasan wisata bahari Gili Meno dan Teluk Nara. Prosiding Loka Karya dan Pengelolaan dan IPTEK Terumbu Karang Indonesia; 1999 November 22-23; Jakarta (ID): Forum Kajian Kelautan UNRAM.

Munro, C. (2013) Diving. Methods for the Study of Marine Benthos (ed. by A. Eleftheriou), pp.125-173. John Wiley \& Sons, Ltd.

Nurhayati S, Henky Irawan, Arief Pratomo. 2015. Hubungan Kelimpahan Drupella sp. Terhadap Kondisi Tutupan Terumbu Karang Di Perairan Pulau Pucung Desa Malang Rapat Kecamatan Gunung Kijang. Jurusan Ilmu Kelautan, FIKP UMRAH

Nybakken, J. W. 1992. Biologi Laut: Suatu Pendekatan Ekologis. Terj. dari Marine Biology: An Ecological Approach, oleh Eidman, M., Koesoebiono, D.G. Bengen, 
M. Hutomo, \& S.Sukardjo. 1992. dari. PT Gramedia Pustaka

1988. Biologi laut: Suatu pendekatan ekologis. Terj. dari Marine biology: An ecological approach, oleh Eidman M., Koesoebiono, Bengen D.G., Hutomo M. \& Sukardjo S., xv + 459 hlm. PT Gramedia, Jakarta.

Pearson RG \& Endean R. 1969. A preliminary study of the coral predator Acanthaster planci (L.) (Asteroidea) on the Great Barrier Reef. Fish Notes 3:27-55.

Piyakornchana T. 1981. Some Ecology Factory limiting Distribution of Acanthaster planci in The Gulf of Thailand. Proceeding 4th International Coral Reefs Symposium.

Romimohtarto, K, Juwana, S. 2007. Biologi Laut: Ilmu Pengetahuan Tentang Biota Laut. Penerbit Djambatan, Jakarta. Ed. Rev.,cet. Ke-3. Hal. 321-332.

Sadarun. B. 2006. Pedoman Pelaksanaan Transplantasi Terumbu Karang. Direktorat Konservasi dan Taman Nasional Laut dan Direktorat Jenderal KP3K. DKP. Jakarta. 36 Hal.

Saputra, W. S. 2009. Status Pemanfaatan Lobster (Panulirus sp) di Perairan Kebumen. Jurnal Saintek Perikanan Vol. 4, No. 2: 10 $-15$

Sari, T.P. 2017. Hubungan Kepadatan Bulu Babi (Echinoidea) dan Tutupan Terumbu Karang pada Kawasan Intertidal Pantai Sanur. Journal of Marine and Aquatic Sciences 3(2), 134-141.

Smith L, M Rees, A Heyward, J ,2002. Colquhoun Stocks of trochus and bêchede-mer at Cartier Reef: 2001 surveys Aus Inst Mar Sci (2002), pp. 1-26

Sugiyono. 2007. Metode Penelitian Administasi. Bandung: Alfabeta.

Suharsono, 2008. Jenis-Jenis Karang yang Umum di Jumpai di Indonesia. LIPI- P3O Proyek Penilitian dan Pengembangan Daerah, Jakarta

----------. 2010. Buku Petunjuk Bagi Pengajar Pelatihan Metodologi Penilaian Terumbu Karang. Jakarta: Lembaga Ilmu Pengetahuan Indonesia.

Terangi, 2007. Pemutihan Karang: Ancaman Bagi Terumbu Karang Indonesia.
Supriharyono, 2000. Pengelolaan Ekosistem Terumbu Karang. Djambatan. Jakarta.

Wulandari, N. M. Kristanti dan D. Elfidasari. 2012. Keragaman Teripang asal Pulau Pramuka, Kepulauan Seribu Teluk Jakarta. Jurnal Unnes of Life Science 1 (2). Fakultas Sains dan Teknologi Universitas Al Azhar Indonesia. 133-139 hal

Suryanti, Supriharyono dan Indrawan, W. 2011. Kondisi Terumbu Karang dengan Indikator Ikan Chaetodontidae Di Pulau Sambangan Kepulauan Karimun Jawa, Jepara, Jawa Tengah. Buletin Oseanografi Marina Vol. 1: 106-119.

Wulandewi, N. L. E., Subagio, J. N., \& Wiryatno, J. 2015. Jenis dan Densitas Bulu Babi (Echinoidea) Di Kawasan Pantai Sanur dan Serangan Denpasar Bali. SIMBIOSIS Journal of Biological Sciences, 3(1), 269- 280.

Yudasmara, G. A. (2013). Keanekaragaman Dan Dominansi Komunitas Bulu Babi (Echinoidea) Di Perairan Pulau Menjangan Kawasan Taman Nasional Bali Barat. Jurnal Sains dan Teknologi, 2(2), 213-220. 